World Conference on Transport Research - WCTR 2016 Shanghai. 10-15 July 2016

\title{
Delusions of success: costs and demand of high speed rail in Italy and Spain
}

\author{
Paolo Beria1 ${ }^{\mathrm{a}}$, Daniel Albalate ${ }^{\mathrm{b}}$, Raffaele Grimaldi ${ }^{\mathrm{a}}$ Germà Bel $^{\mathrm{b}}$ \\ ${ }^{a}$ Department of Architecture and Urban Studies (DAStU), Politecnico di Milano, Italy \\ ${ }^{b}$ Dep. Política Econòmica, Universitat de Barcelona, Spain
}

\begin{abstract}
Mismatches between forecasted and actual costs and traffic figures are common in transport investments, especially in large scale ones, and so are delusions on future demand. High-speed rail project are often among the worst practices for cost overruns and demand overestimation, even where traffic figures may tell a history of apparent success.

In the paper, we analyse two significant cases of delusion of success, namely Italian and Spanish HSR programmes. The Italian one shows excellent demand performances, but is among the continental worst cases for construction costs. The Spanish one, recognised worldwide as one of the most successful cases, is the one where potential demand estimations was systematically neglected and the planned network appears largely out-of-scale compared to actual traffic. The two cases show that the core of the problem does not lay in the wrong estimations of costs and demand, but on deliberate choices of overinvestment, overdesign and overquality.
\end{abstract}

(C) 2017 The Authors. Published by Elsevier B.V.

Peer-review under responsibility of WORLD CONFERENCE ON TRANSPORT RESEARCH SOCIETY.

Keywords: High-speed rail, megaprojects, Italy, Spain, cost overrun, demand estimation, optimism bias

1 Corresponding author. Tel.: +39-02-2399-5424; fax: +39-02-2399-5435.

E-mail address: paolo.beria@polimi.it 


\section{Introduction}

Many European countries underwent, since the end of the XX Century, huge High Speed Rail (HSR) programmes, following the tracks opened by the French TGV and the Japanese Shinkansen. Decades after these programmes started, HSR megaprojects are often among the worst practices for cost overruns and demand overestimation, even where traffic figures may tell a history of apparent success.

In fact, the appreciation of customers and of local authorities for high-speed rail services hides, also in the best practices, a number of problems. Large networks may change the mobility of regions, but the construction of hundreds, where not thousands, of kilometres of new lines have placed a burden on the budget of many countries. The high costs are, sometimes, amplified by the framework conditions, made of environmental mitigations, interconnections, passage through densely built areas, etc., but also by the scarce competition in civil works and by regulatory frameworks.

A second issue lays in the demand. The success of a HSR system is often measured in terms of induced modal change from air and car. But modal change is not the only goal and many of these lines remain largely underused, at least with respect to potential capacity. In few cases cost-benefit analyses have been produced to quantify the surplus gains and compare them with additional costs with respect to reference solutions, typically conventional rail and air transport, or even with less performing solutions such as improvements of conventional rail, new rolling stock, selective doublings, etc.

In the paper we will address the problems of HSR by studying in deep the Italian and Spanish cases, because showing significant problems of cost overruns and weak demand. With respect to traditional approach to optimism bias (Flyvbjerg et al., 2003), more focusing on mismatches and deliberate manipulation of project documentation, we discuss the design and planning choices at the roots of the problems of the two cases. In particular, we recognise three phenomena: overinvestment, overdesign and overquality. We also try to explain them in terms of the fundamental causes, which lay in the governance process.

The paper is structured as follows. After an introduction to the HSR models adopted in Europe, we propose a description of the two national programmes as planned and implemented. Using available data, we show and compare traffic and cost figures in the two cases and versus comparable benchmarking situations, evidencing where the most relevant failures are. Subsequently, we comment the failures and their causes, with particular reference to the decisional processes and regulatory contexts present in the two countries

\section{High Speed Rail models in Europe}

High Speed Rail is not a transport mode per se, but a particular way of providing rail transport, with higher performance standards. These standards derive from the combination of services and infrastructure: it is possible to have high-speed services on a conventional infrastructure and conventional services on a high-speed infrastructure.

Campos and de Rus (2009) suggest four different exploitation models for HSR infrastructure:

- An exclusive exploitation model, with complete separation between conventional and high speed services (the Japanese Shinkansen model);

- A mixed high-speed model, with high-speed trains running on both specific and conventional infrastructure (the French TGV model);

- A mixed conventional model, with some conventional trains running on high-speed infrastructure (the Spanish AVE model); and,

- A fully mixed model, where both conventional and high-speed trains can run on either conventional or high speed infrastructure (the German ICE model).

Perl and Goetz (2015) instead propose three more geographically focused models:

- exclusive corridors, between megacities of more than 10 million inhabitants (e.g., in Japan),

- hybrid networks, made of new HSR links connecting conventional rail lines, which remain crucial, multiplying the number of origins and destinations to be served (e.g., in France); and,

- comprehensive national networks, with new infrastructure linking all major and mid-sized communities across the country (e.g. in Spain).

Within these models, the same authors suggest that networks may take different forms (e.g. hybrid networks can be radial as in France or decentralized as in Germany).

\section{The Italian "TAV - Treno Alta Velocità"}

\subsection{The history of the programme}

When it was first conceived, in 1990, the Italian HSR (in Italia "Alta Velocità", from here on AV) was to be a new 
system, substantially independent from the rest of the network. It aimed at providing faster connections among the cities of Turin, Milan, Bologna, Florence, Rome and Naples (RFI, 2007), which can be considered the "backbone" line of the country. This network should have been built through Project Financing by a new mixed society, called $T A V \operatorname{SpA}$, with a $60 \%$ of private capital to be completely repaid and the rest owned by the Italian state.

This initial model was soon changed into a new high performance doubling of the existing network, thanks to many interconnections with the existing conventional network, but maintaining a different voltage. ${ }^{2}$ The existing HS line from Florence to Rome was included in this network. In 1996 the name of the planned system changed to “Alta Velocità/Alta Capacità" (High Speed/High Capacity in Italian), as the concept was once again changed into a system capable to host also heavy freight trains thanks to lower slopes.

However, already in 1998, the State had to buy back the entire stock of shares of TAV, due to the unavailability of private shareholders to provide entitled capitals (RFI, 2007). The process of re-nationalisation of TAV SpA lasted from 2000 to 2007 and ended with the forced take-over of 13 billion Euros of TAV debts by the State balance (Beria and Ponti, 2009). Today TAV SpA is no more operative as a project-financing subject.

\subsection{Realised and planned network}

The construction of the first phase took a decade and was completed in 2009. The Turin-Salerno axis allows trains to run at $300 \mathrm{~km} / \mathrm{h}$, excluding the older Florence-Rome section, the Naples-Salerno (both at $250 \mathrm{~km} / \mathrm{h}$ ) and the urban sections.

Also the two extremity sections of the Milan-Venice axis have been completed (Milan-Treviglio and PaduaVenice) and in operation at 200-250 km/h. An upgrade of the Verona-Bologna line opened in 2009, rising its speed at $200 \mathrm{~km} / \mathrm{h}$, and a new urban section in Bologna (underground, including a new station under the existing one) opened in June 2013. ${ }^{3}$

\begin{tabular}{|c|c|c|c|c|c|c|}
\hline Section & Opening year(s) & $\begin{array}{l}\text { Maximum } \\
\text { speed } \\
{[\mathrm{km} / \mathrm{h}]}\end{array}$ & Voltage type & $\begin{array}{l}\text { Lenght } \\
\text { [km] }\end{array}$ & $\begin{array}{l}\text { Max. } \\
{[\%]}\end{array}$ & Slope \\
\hline \multicolumn{7}{|l|}{ Turin - Salerno axis } \\
\hline Turin - Milan & $2006-2009$ & 300 & $25 \mathrm{kV} \mathrm{AC}$ & 125 & & 14.8 \\
\hline Milan - Bologna & 2008 & 300 & $25 \mathrm{kV} \mathrm{AC}$ & 182 & & 15.0 \\
\hline Bologna - Florence & 2009 & 300 & $25 \mathrm{kV} \mathrm{AC}$ & 79 & & 15.0 \\
\hline Florence-Rome & 1977 - 1992 & 250 & $3 \mathrm{kV} \mathrm{DC}$ & 254 & & 12.0 \\
\hline Rome - Naples & $2005-2009$ & 300 & $25 \mathrm{kV} \mathrm{AC}$ & 205 & & 21.0 \\
\hline Naples - Salerno & 2009 & 250 & $3 \mathrm{kV} \mathrm{DC}$ & 29 & & 18.4 \\
\hline \multicolumn{7}{|l|}{ Milan - Venice axis } \\
\hline Milan - Treviglio & 2007 & 200 & $3 \mathrm{kV} \mathrm{DC}$ & 27 & & 12.0 \\
\hline Padua-Venice & 2006 & 220 & $3 \mathrm{kV} \mathrm{DC}$ & 25 & & 12.0 \\
\hline \multicolumn{7}{|l|}{ Other lines } \\
\hline Verona - Bologna & 2009 & 200 & $3 \mathrm{kV} \mathrm{DC}$ & 114 & & 12.0 \\
\hline
\end{tabular}

Table 1. Italian high-speed network operating sections (June 2011).

The latest versions of the Infrastructure Annex of the "Economic and Financial Document" (DEF) of the Italian government (which is the only official planning document to date in Italy) envisaged new lines to be built between Milan and Venice (central sections), Milan and Genoa, Bari and Naples and towards the southern regions. Moreover, huge projects involved new high performance lines towards neighbour countries through Alps, in particular the Frejus line (Turin-Lyon) and the Brenner line (Verona-Munich).

However, since 2011, the scarcity of public funds somehow forced a new political address to downgrade the design characteristics and to prefer selective doublings or technological upgrades (ResPublica, 2010). In the last version (2015) of the DEF only a small part of those lines were confirmed and partially financed (with only 2,000 M€ overall in three years), while the others were claimed to need further analysis and consultation with local

\footnotetext{
${ }^{2}$ High-speed lines operate at 25kV AC, while the traditional network, including the urban terminals of high-speed lines into cities, operate at $3 \mathrm{kV} \mathrm{CC}$

${ }^{3}$ The new section allowed time savings of about 5 minutes for non-stop services but its main purpose was to free up capacity in the existing station and urban section for suburban and regional services.
} 
administrations.

\subsection{The model adopted}

Italian rail infrastructure is, thanks to liberalisation in 2003, open to on-track competition. Differently from the other few EU cases, Italian on-track competition is mainly concentrated in the high-speed segment with a highspeed specialised rail company, NTV (Beria et al., 2014), whose train “.Italo" is competing with Trenitalia highspeed branded services, "leFrecce".

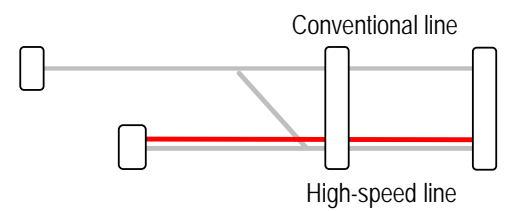

"Frecciarossa" and "Italo"

Fully high-speed services

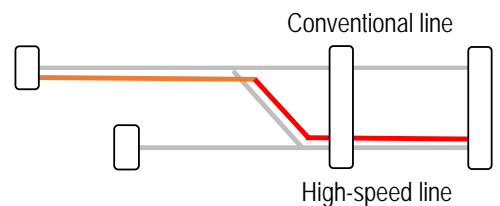

"Frecciarcento" and "Italo" Mixed high-speed and conventional services

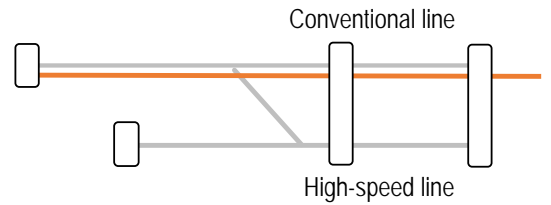

"Frecciabianca"

Fully conventional services

Figure 1. Schematisation of the mixed high-speed model used in Italy.

The model adopted in Italy so far is somehow derived from the French one, i.e. a mixed high-speed model, as defined by Campos and de Rus (2009), and hybrid networks as defined by Perl and Goetz (2015). Both companies operate mixed services (conventional and high-speed) using high-speed rolling stock, as schematised in Figure 1. In particular, some high-speed trains (branded Frecciargento by Trenitalia and operating at $250 \mathrm{~km} / \mathrm{h}$ max) run on high-speed where available and conventional infrastructure to serve more origin-destination pairs than those directly connected to HSR infrastructure (e.g., Venice-Rome or Bari-Rome). Frecciarossa trains, instead, operate on dedicated tracks only and can reach $300 \mathrm{~km} / \mathrm{h}$. Figure 2 maps show both frequencies and seats capacity of all Trenitalia and NTV trains using the high-speed infrastructure.

As we will see in the following sections, this model proved to fit quite well the mobility on the North-South "backbone" of the country, where long distance trips between Milan and Rome constitute a large share of mobility. In other contexts, such as the planned Milan - Venice line a German fully mixed model would better fit the demand dynamics (Beria \& Grimaldi, 2011). In this context the need to serve a wide metropolitan region with middle-sized towns and shorter mobility patterns (less than $200 \mathrm{~km}$ ), prevails on the "need for speed" typical of $400-800 \mathrm{~km}$ routes. $^{4}$

As already mentioned, interconnections and line characteristics would theoretically allow the use of the high-speed lines by dedicated high-speed freight trains, as foresaw by decision-makers at the moment of planning. However, to date, not a single freight train used the new lines and, not surprisingly in our opinion, no operator seems to be willing to invest in it.

\footnotetext{
${ }^{4}$ Despite its very important touristic role, the Larger Urban Zone of Venice had only 493k inhabitants in 2012, to be compared with 500k of Padua, 504k of Verona and 462k of Brescia (Eurostat, 2015).
} 

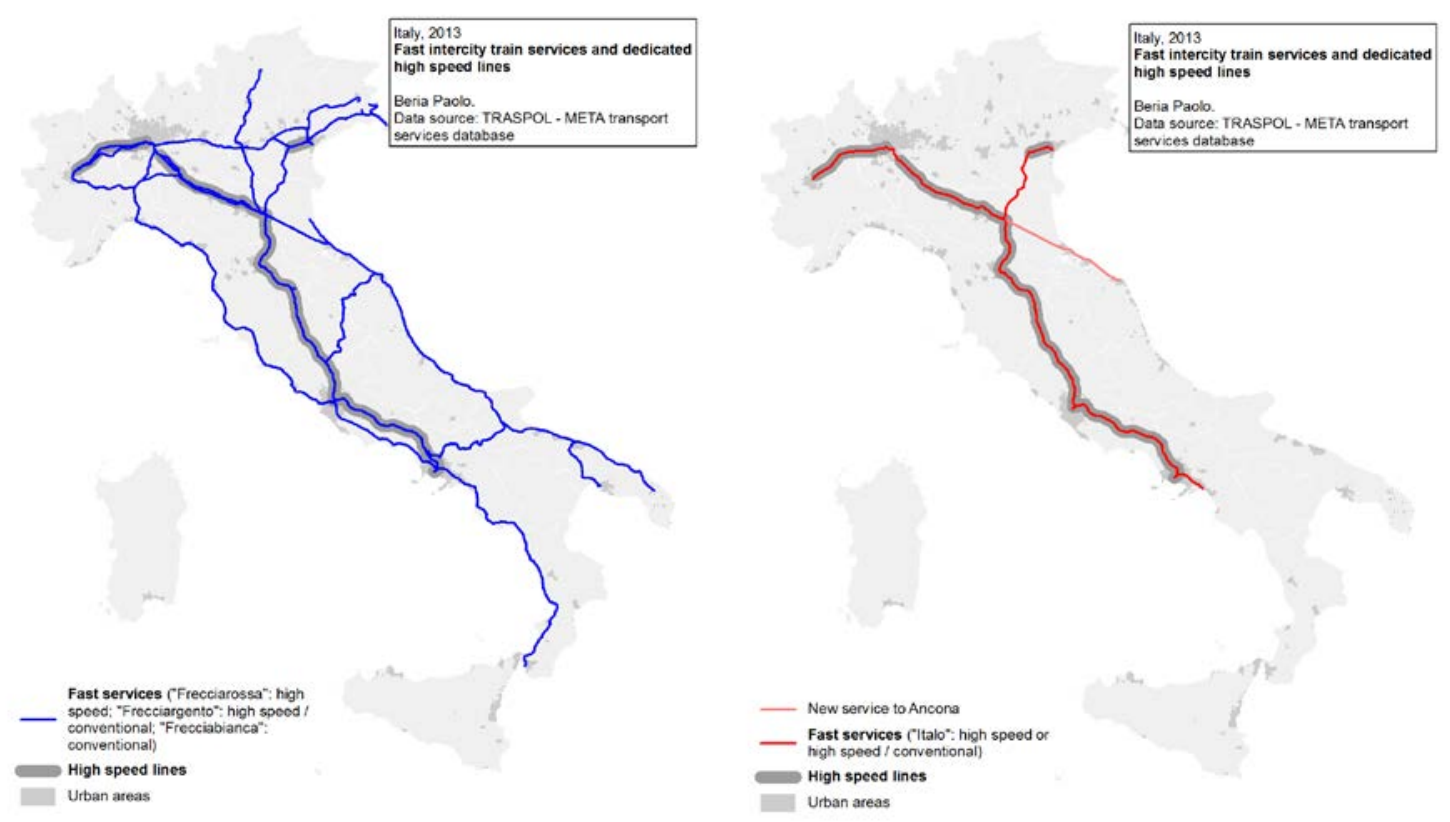

Figure 2. The network of Italian fast trains, including full high speed ones (Frecciarossa, Frecciabianca, Frecciargento, Italo).

\section{The Spanish “AVE - Alta Velocidad Española”}

\subsection{The history of the programme}

After decades of sustained loss of competitiveness and attractiveness respect to road and air transportation (Bel, 1997), the Spanish government decided to modernize the railway in the late 1980s. Quite controversially, the first route to benefit from a modernization - with a new track of international width (UIC) and high-speed performance - was the Madrid-Seville. This route was not connected with France and the rest of the European railway system. ${ }^{5}$ Moreover, it was decided not to start by the densest route, Madrid-Barcelona, as has been usual in high-speed rail world experiences (See Albalate and Bel, 2012a,b). On the other, a railway modernization project keeping Iberian gauge and services at speeds up to 200-220 was promoted along the Mediterranean corridor (Barcelona-Valencia) in parallel. This was one of the densest corridors in Europe and a historical link between the peninsula and center of the Continent. The Madrid-Seville choice for the first high-speed rail with standard gauge was justified by the need to mitigate the extreme congestion experienced at the Despeñaperros pass, as well as with other political arguments unrelated to transportation or efficiency goals.

As a result, the first high-speed railway entered into service in 1992, shortly before the inauguration of the Universal Exposition of Seville, with intermediary stations at Ciudad Real, Puertollano and Cordoba. However, high-speed rail did not experience additional developments until year 2000, when it became a centerpiece of infrastructure planning. The central government's enormous spending on high-speed rail since 2000 is based on a goal established by Aznar's government in 2000. ${ }^{6}$ The purpose of the program was to connect the country's political and economic capital, Madrid, to all of the provincial capitals by high-speed rail in less than 4 hours. The following Socialist government later confirmed the policy and further reduced the objective to 3 hours. $^{7}$

This goal and the routes designed by the plan were not supported by mobility needs or congestion cost mitigation objectives, but by the administrative role of cities as provincial capitals regardless their population, their travel demand to/from Madrid and the presence of other modes of transportation already serving the route. On the contrary, it arises from an understanding that high-speed rail and its connection with the political and economic capital would favor territorial cohesion and regional development. For this reason the program can hardly be understood as a transportation policy, especially because design did not consider the potential of passenger volumes and time savings respect to investment efforts, or its interaction with other modes of transportation already in place.

\footnotetext{
${ }^{5}$ Note that conventional lines in Spain are designed with a track gauge width of $1668 \mathrm{~mm}, 233$ mm wider than the international gauge. This difference supposed a serious mobility obstacle that hindered the Spanish economic relations with the rest of Europe.

${ }^{6}$ Investiture debate for the 2000-2004 legislation (Diario de Sesiones del Congreso, 2000, $\mathrm{n}^{\circ}$ 2, (April 25), p. 29).

${ }^{7}$ Strategic Plan for Infrastructures and Transportation 2005-2020, at the end of 2004.
} 
The first route inaugurated in this second stage of the high-speed rail development was the Madrid-Zaragoza route in 2003, as a first section of the future Madrid-Barcelona-France corridor (Norteastern Corridor) that would arrive to Barcelona in 2008 and to France - with direct services - in 2013. Currently, after a period of dynamic development and public investment, there are 4 high-speed rail corridors in operation connecting Madrid to the French Border, to Andalusia, to the Mediterranean coast (Levante) and to the Northern corridor to Valladolid, Palencia and León. Also a first phase of the Madrid-Galicia is already in service in both extremes (A CoruñaOurense and Olmedo-Zamora) awaiting for the continuation between Ourense and Zamora.

\subsection{Realised and planned network}

Because the development of the high-speed rail network has been the main protagonist of transportation policy since 2000 and the centerpiece of infrastructure planning and investment, Spain has rapidly become the European leader of high-speed rail infrastructure in terms of length of its network (Albalate, Bel and Fageda, 2015). Moreover, Spain ranks second in the world today only behind China, and persists in extending the network in order to complete the objective of connecting all provincial capitals to Madrid. Figure 1 shows how Spain has built most of this extensive network in less than 15 years, revealing the intensity of investments devoted to this project in the recent years. The current network with its lines and main cities connected is shown in figure 2 . Table 1 describes the lines considered by ADIF as high-speed rail lines - even if some of them do not permit speeds of $250 \mathrm{Km} / \mathrm{h}$-, indicating their length and maximum speed of design for commercial services.

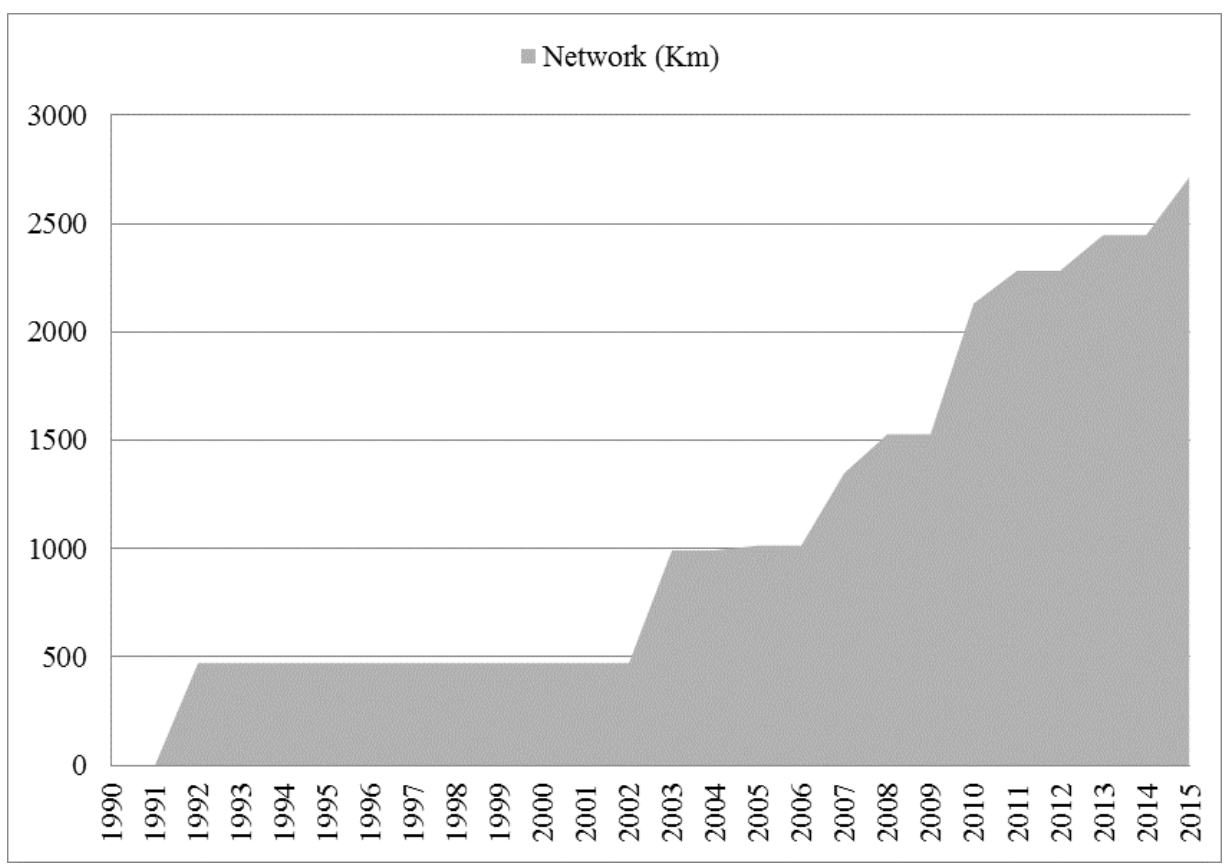

Figure 3. Length of the High-speed Rail network in Spain, 1992-2015. Source: authors’ elaborations 


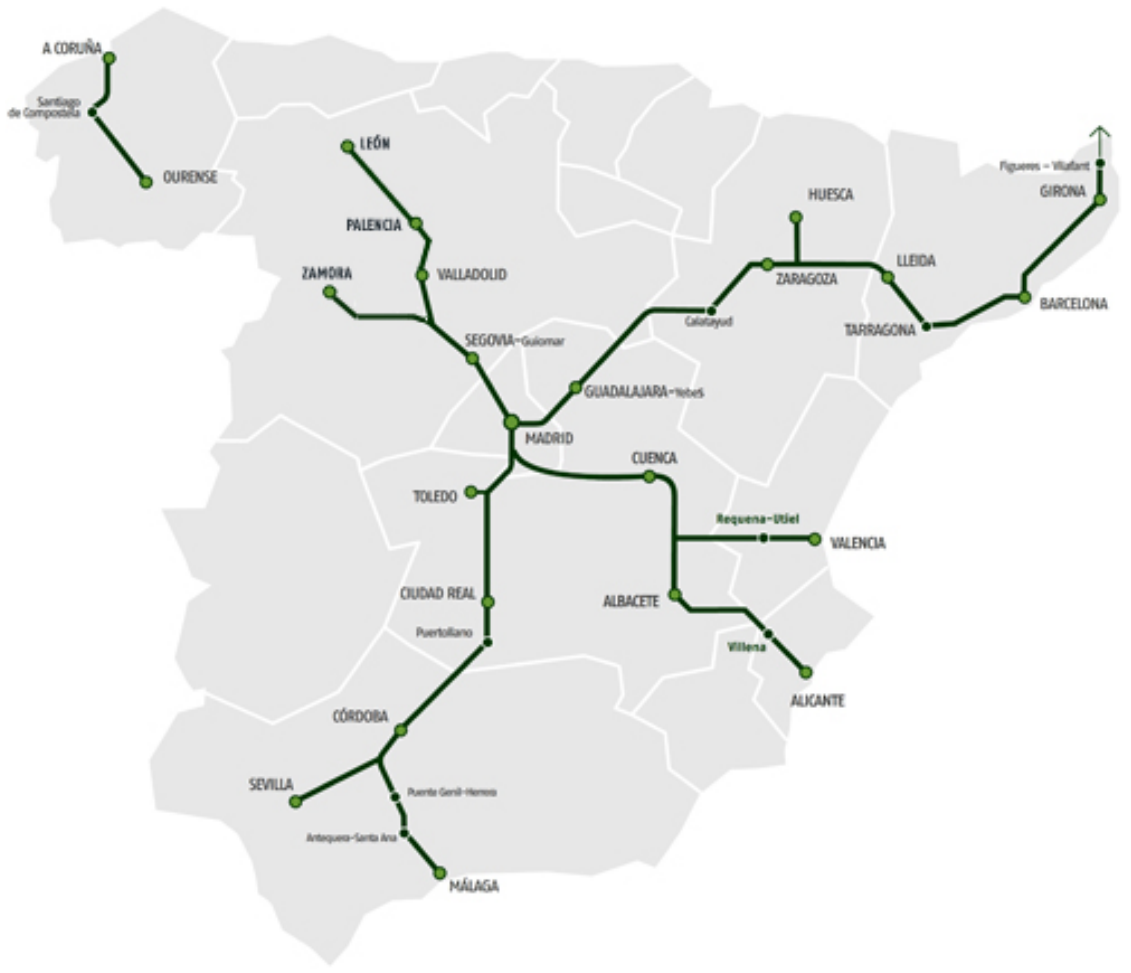

Figure 4. High-speed Rail network in Spain, March 2016. Lines considered HSR by Adif. Source: Adif.

\begin{tabular}{lccc}
\hline Section & Opening year & Maximum speed [km/h] & Length [km] \\
\hline Madrid-Andalucía & 1992 & 300 & $\mathbf{6 4 8}$ \\
Madrid-Seville & 2005 & 270 & 472 \\
La Sagra-Toledo & 2007 & 300 & 21 \\
Córdoba-Málaga & & & 155 \\
\hline Madrid-Northwest & 2007 & 300 & $\mathbf{3 4 6}$ \\
\hline Madrid-Valladolid & 2015 & 200 & 180 \\
Valladolid-León & & & 166 \\
\hline Madrid-French Border & $2003^{\text {a }}$ & 300 & $\mathbf{8 3 1}$ \\
Madrid-Lleida & 2003 & 200 & 442 \\
Zaragoza-Huesca & 2008 & 300 & 79 \\
Lleida-Barcelona & $2010^{\mathrm{b}, \mathrm{c}}$ & 300 & 179 \\
Barcelona-Figueres & & & 131 \\
\hline Madrid-Levante & 2010 & 300 & $\mathbf{6 3 7}$ \\
\hline Madrid-Albacete & 2010 & 300 & 322 \\
Bifurcation Albacete-Valencia & 2013 & 300 & 150 \\
Albacete-Alicante & & & 165 \\
\hline Madrid-Galicia & 2011 & 300 & $\mathbf{2 5 0}$ \\
Santiago-Ourense & 2011 & 200 & 88 \\
A Coruña-Santiago & 2015 & 200 & 62 \\
Olmedo-Zamora & & & $\mathbf{2 , 7 1 2}$ \\
\hline Total & & & \\
\hline
\end{tabular}

a. Note that high-speed infrastructure arrived to Lleida in 2003 but AVE services at $250 \mathrm{Km} / \mathrm{h}$ did not start until 2006. Prior services were travelling at maximums speeds of $200 \mathrm{~km} / \mathrm{h}$.

b. Distance from Barcelona to the municipality of Figueres where starts the concession of TP Ferro on the Le Perthus Tunnel and the infrastructure links between Figueras and Perpignan (France). The link in the Spanish territory covers $19 \mathrm{Km}$, from a total of $44 \mathrm{Km}$.

c. As in the previous case, direct services with high-speed rail services ( $>250 \mathrm{~km} / \mathrm{h})$ connecting Barcelona to Figueras did not start until 2013.

Table 2. Spanish high-speed network operating sections. 
As a result, Spain enjoys a high-speed rail network of more than 2,700 km. Further works are carried out to complete new lines or to extend current links, in some cases using a mix of new standard gauge and upgraded sections, to be used by specific interoperable rolling stock. ${ }^{8}$ Plans include extensions north to Oviedo, Ourense, Burgos and to the province capitals of the Basque country, and south to Granada and Cadiz; a link to Extremadura is also being considered.

\subsection{The model adopted}

From the variety of possible combinations of infrastructure features, Spain opted for separate tracks disconnected from the existing conventional infrastructure. This decision meant greater spending on construction and particularly in the expropriation of land in urban areas. However, it also provided services at higher speeds promoting the competitiveness of this mode of transportation respect to other modes, particularly air transportation. Most high-speed rail lines are designed to achieve maximum speeds between 300 and $350 \mathrm{~km} / \mathrm{h}$. However, there are some exceptions is what is still considered high-speed lines, in which the services only operate at 200-220 $\mathrm{km} / \mathrm{h}$ by means of a modernization of conventional lines.

In this respect, the government started an investment rationalization strategy for new lines that have been translated into the adaptation of conventional lines to high-speed services by constructing variants of great magnitude and catenaries prepared for an electrification of $25 \mathrm{kV}$ or $3 \mathrm{kV}$ partly prepared to $25 \mathrm{kV}$. They have maintained the Iberian gauge but sleepers and track equipment are ready for a change to standard or international width. This allows for speeds up to $200-220 \mathrm{~km} / \mathrm{h}$ and up to $250 \mathrm{~km} / \mathrm{h}$ with a change of width. This strategy was chosen for the $55 \mathrm{Km}$ between Alcazar and Albacete (Madrid-Levante corridor), for the $157 \mathrm{~km}$ between A Coruña and Vigo or for the link between Cadiz and Sevilla.

Spain also opted for high-speed rail infrastructure with a clear orientation to passengers, leaving only a marginal role for freight. This choice left freight traffic mainly to the conventional network, with the relevant exception of the line connecting the French border. This decision was also controversial, considering that Spain has one of the lowest market shares of rail freight transportation.

Another characteristic of the model chosen is that Spain has used foreign technology, mainly French and German (Vickerman, 1997). However, agreements included that at least $80 \%$ of material manufacture had to be produced in Spain favouring the national industry. Signaling systems of the Spanish network rely basically on ASFA, (Announcement of Signals and Automatic Braking), LZB (continuous train control), and ERTMS1 and ERTMS2 (European Rail Traffic Management System), depending on the line. ${ }^{9}$

Another element of Spanish high-speed rail model is its centralization around the political capital following a unique and exclusively radial design, as much in the development stage as in the planned, final goal (Albalate, Bel and Fageda, 2012). In this respect, the case of Spain resembles that of politically centralized States with urban systems of satellite cities around a large hub, as is the French case with Paris, which has reproduced this layout in the design of their high-speed networks (See Albalate and Bel, 2012b). In contrast, the territorially decentralized states with structures of dispersed cities in the territory, such as Germany and Italy, have reproduced a dispersed and decentralized design, without a hub that systematically enjoys greater accessibility and connectivity in the network.

\section{Demand figures}

\subsection{Italy}

There exist no publicly available data on disaggregated patronage of existing High-Speed lines and services in Italy. In a past work, we estimated the 2011 patronage, based on supply levels and some punctual figures (Beria \& Grimaldi, 2011). A more recent work (Dell'Alba \& Velardi, 2015) provides figures with a similar detail for 2013. Table 3 reports the results of those unofficial disaggregated estimates for comparison. Values refer to the “core area” as defined in Dell’Alba \& Velardi, 2015, which includes trains of the Turin - Salerno axis and the Bologna - Venice branch only, and include both competitors Trenitalia and NTV.

\footnotetext{
${ }^{8}$ In terms of gauge and electric power supply.

${ }^{9}$ ERTMS (European Rail Traffic Management System) is distinguished in level 2 because communication is bidirectional, between the train and the control center, and is done continuously, thanks to a transmission system similar to mobile phones information, called GSMR.
} 
Table 3. Million passengers travelling on line sections. Sources: 2013 figures, our elaborations on Dell'Alba \& Velardi (2015); 2011 figures (rounded central value), Beria \& Grimaldi (2011).

\begin{tabular}{cccc}
\hline Line section & 2011 & 2013 & Increase \\
& Trenitalia & Trenitalia + NTV & \\
\hline Torino - Milano & 1.5 & 4 & $+167 \%$ \\
Milano - Bologna & 6.5 & 13 & $+100 \%$ \\
Bologna - Firenze & 11 & 18 & $+64 \%$ \\
Firenze - Roma & 9.5 & 17.5 & $+84 \%$ \\
Roma - Napoli & 3 & 7.5 & $+150 \%$ \\
\hline
\end{tabular}

The central sections of the Italian network, from Bologna to Rome, are the ones with the highest number of passengers, around 18 million per year. This section collects the three northern branches of HS services from Turin and Milan (the most important, with 13 Mpax), from Verona (not included in this figures) and from Venice. The extreme segments, Milan - Turin and Rome - Naples, are the less crowded.

The trend of patronage is more impressive than absolute values. In just two years, the central segments increased of $+60 \div+100 \%$ and the extreme ones of more than $+150 \%$, i.e. more than doubled. The explanation is twofold. On one side part of the increase is due to the increasing maturity of the system (fully opened in 2009), but the majority is surely due to the competition developed since 2012 thanks to the entrance of NTV, providing more capacity and forcing Trenitalia to significantly lower both the cheapest and average fares. This allowed more passengers with lower willingness to pay to access the system and overall increased the number of trips.

An indirect demonstration of the capability of HS to attract new passengers comes not only from the severe financial problems of Alitalia, whose Linate - Fiumicino route has been for long a never-ending source of profits, but also from the entry and sudden exit of low cost carriers (easyJet in particular) from a route with very low yields.

Table 4. Aggregate supply and demand value.

\begin{tabular}{|c|c|c|c|}
\hline & $\begin{array}{c}2011 \\
\text { Trenitalia } \\
\end{array}$ & $\begin{array}{c}2013 \\
\text { Trenitalia }+ \text { NTV } \\
\end{array}$ & Increase \\
\hline Million passenger & $18.7 * *$ & $30.8^{*}$ & $+65 \%$ \\
\hline Million passenger-km & $5,601 * *$ & $12,296 *$ & $+120 \%$ \\
\hline Trains-km (average weekday) & $76,195^{*}$ & $120,897 *$ & $+59 \%$ \\
\hline Services (average weekday) & $120^{*}$ & $184^{*}$ & $+53 \%$ \\
\hline Load factor (average) & 201.4 & 278.6 & $+38 \%$ \\
\hline Million Pax-km/km of lines & $5.48 * * *$ & $12.03 * * *$ & \\
\hline $\begin{array}{l}\text { * our elaboration on Dell'Alba \& Velard } \\
* * \text { our elaboration on Beria \& Grimaldi } \\
* * * \text { calculated dividing the passenger-k } \\
\text { conventional. }\end{array}$ & length of all line & , including the Bol & a-Padova, \\
\hline
\end{tabular}

Table 4 gives evidence not only that the passengers increased (+65\% from 18.7 to $30.8 \mathrm{Mpax}$ ), but that the distance travelled increased moreover $(+120 \%)$. The total frequency and the supply increased slightly less, determining also a $+38 \%$ in load factors. This let us infer that the entry of NTV (together with the maturity of Trenitalia offer) did reduce Trenitalia share, but not its passengers, as total demand increased significantly and even more than the increase of supply. Even if we have no evidence of that, ${ }^{10}$ we can expect a decrease is the margin of the train companies, all in favour of travellers. With all the limits of this kind of aggregate indicators, also the density of passengers per km of lines dramatically increased, from 5 to $12 \mathrm{Mpax}-\mathrm{km} / \mathrm{km}$.

In conclusion, Italian figures are more impressive for the trend and for its causes, than for the absolute number of

\footnotetext{
${ }^{10}$ The balance sheet of Trenitalia is not disaggregated enough to allow separate financial performances of high-speed services with respect to conventional ones.
} 
passengers travelled, which is significant, but remains below the top densely used lines in Europe.

\subsection{Spain}

HSR passengers (both medium- and long-distance) increased from 8.2 milion in 2006 to 26.1 in 2015, according to figures by the Ministry of Transportation. This figure only represented the $6 \%$ of total rail passengers in the country in 2015 (it was 2\% in 2006). Regarding HSR passengers-km, they grew from 2.3 billion in 2006 to 9.5 in 2015.

Information regarding main origin-destination connections is displayed in table 3, where we can observe that the main link Madrid-Barcelona only received 3 million passengers per year. All the rest of routes are far from reaching to this figure and present demand figures well below of this volume. Table 4 also reports the number of trains-km. There were 45 million trains-km offered in 2013, the last available year.

\begin{tabular}{lcc}
\hline $\begin{array}{c}\text { Main O-D connections } \\
\text { (>1 million passengers) }\end{array}$ & $\mathbf{2 0 1 2}$ & $\mathbf{2 0 1 3}$ \\
\hline Madrid-Sevilla & 2.1 & - \\
Madrid-Barcelona & 2.7 & 3.1 \\
Madrid-Valencia & 1.8 & 1.9 \\
Madrid-Málaga & 1.4 & 1.3 \\
Madrid-Zaragoza & 1.2 & - \\
Madrid-Valladolid & 1.1 & 1.2 \\
\hline
\end{tabular}

Table 5. Total volume of passengers in high-speed rail and long distance services. Source: Ferropedia.

\begin{tabular}{lrrr}
\hline Corridor & $\mathbf{2 0 0 8}$ & $\mathbf{2 0 1 0}$ & $\mathbf{2 0 1 3}$ \\
\hline Madrid-Valladolid & $2,235,590$ & $2,465,327$ & $3,071,278$ \\
Madrid - French Border & $12,547,474$ & $16,211,184$ & $16,721,919$ \\
Madrid-Levante & - & 340,072 & $6,881,309$ \\
Madrid-Andalucia & $17,246,934$ & $18,456,918$ & $18,355,540$ \\
\hline Total & $\mathbf{3 2 , 0 2 9 , 9 9 8}$ & $\mathbf{3 7 , 4 7 3 , 5 0 2}$ & $\mathbf{4 5 , 0 3 0 , 0 4 6}$ \\
\hline
\end{tabular}

Table 6. Traffic volume of trains-km. Source: Tribunal de Cuentas (2015).

\section{Construction costs}

\subsection{Italy}

According to initial plans, the costs of the Turin-Salerno axis was expected to be 10.7 billion€ in 1992. In 2006, before the conclusion of the works, rose to 32.0 billion€, meaning a doubling of costs in real terms (RFI, 2007) ${ }^{11}$. But cost escalation is not the main problem. In fact, the cost per km reached, on average, $32 \mathrm{M€} / \mathrm{km}$, much higher than in any comparable case in Europe and also much higher than reported in literature (Campos et al., 2009 and Nash, 2015), also considering the different orographic and land use characteristics. ${ }^{12}$

\footnotetext{
${ }^{11} 10.7$ billion Euro $_{1994}$ is equal to 15.5 billion Euro $_{2006}$ (RFI, 2007).
}

12 The cost of lines in France was $10 \mathrm{M€} / \mathrm{km}$ and $9 \mathrm{M€} / \mathrm{km}$ in Spain. 


\begin{tabular}{|c|c|c|c|c|c|}
\hline Section & $\begin{array}{c}\text { Investment cost } \\
M €\end{array}$ & $\begin{array}{c}\text { Cost per } \mathrm{km}^{*} \\
\mathrm{M} € / \mathrm{km}\end{array}$ & Line description & $\begin{array}{c}\text { Travel time } \\
1999 \\
\end{array}$ & $\begin{array}{c}\text { Travel } \\
\text { time } \\
2011 \\
\end{array}$ \\
\hline Turin - Milan & 7,788 & 54 & $\begin{array}{l}\text { Plain line in agricultural area, } \\
\text { along the highway }\end{array}$ & 1h 35’ & 1h 03’ \\
\hline Milan - Bologna & 6,916 & 31 & $\begin{array}{l}\text { Plain line in agricultural area, } \\
\text { along the highway }\end{array}$ & 1h 42’ & 1h 05' \\
\hline Bologna - Florence & 5,877 & 68 & $\begin{array}{l}\text { Semi-continuous tunnel in } \\
\text { complex rock }\end{array}$ & 50 ' & $36^{\prime}$ \\
\hline Rome - Naples & 5,671 & 24 & $\begin{array}{l}\text { Plain / hilly line in agricultural } \\
\text { area }\end{array}$ & 1h $45^{\prime}$ & 1h 10’ \\
\hline
\end{tabular}

Table 7 - Investment costs per section and travel times (our elaboration on RFI, 2007, and Beria \& Grimaldi, 2012)

\subsection{Spain}

The Strategic Plan for Infrastructures and Transportation (PEIT) foresaw 43.7\% of spending made in the period 2005-2020 to be dedicated to interurban rail. Within the railway mode, high-speed rail was planned to receive three-quarters of the interurban railway spending, amounting to 33.5\% of the total investment (Bel, 2007). The driving idea behind AVE planning is to connect all of Spain's provincial capitals with Madrid by 2020.

The investment for the extension of the AVE has been very high. The gross cost of the first line, Madrid-Seville, was $\$ 3.5$ billion in 1992 (de Rus and Inglada, 1993, p. 37), amounting to more than \$6 billion in 2010 terms (Albalate and Bel, 2012b). A recent report of the Accounting Court (Tribunal de Cuentas, 2015) indicated that ADIF had spent by the end of 2013 about 56.5 billion euro, being 44.2 billion euro investments already realized. Because these figures do not include the spending of the lines built before $2007,{ }^{13}$ we can estimate that the volume of spending made on AVE activities up until the end of 2013 was well over 60 billion (Contracted) and close to 50 billion (executed), including lines in service and lines under construction.

Regarding specific lines, we can provide some investment figures in table 6 that have been obtained from Betancor and Llobet (2015) at corridor level - only those opened by 2013, given that their study provides homogeneous figures in constant euro of 2013, which allows for a comparison. As can be observed, Spanish construction cost per $\mathrm{km}$ is relatively cheaper than the construction cost in other experiences that are comparable. Albalate and Bel (2015) compare recent high-speed rail projects in the world and find that Spain, only after China, is the country presenting the lowest average cost per $\mathrm{km}$ within a group of countries that includes other more expensive experiences as France, Germany, Japan, Korea, Taiwan and Italy.

\begin{tabular}{lrrr}
\hline & $\begin{array}{r}\text { Investment cost } \\
\mathrm{M} €\end{array}$ & $\begin{array}{r}\text { Length } \\
\mathrm{km}\end{array}$ & $\begin{array}{r}\text { Cost per km } \\
\mathrm{M} € / \mathrm{km}\end{array}$ \\
\hline Madrid-Andalucía $^{\mathrm{a}}$ & 5,584 & 627 & 8.9 \\
Madrid-Barcelona $^{\mathrm{b}}$ & 7,541 & 700 & 10.8 \\
Madrid-Levante $^{\mathrm{c}}$ & 5,882 & 637 & 9.2 \\
Madrid-Valladolid & 3,871 & 180 & 21.5 \\
\hline
\end{tabular}

a Includes Madrid-Sevilla and Córdoba-Málaga. Excludes La Sagra-Toledo.

${ }^{\mathrm{b}}$ Includes Madrid-Lleida-Barcelona and Zaragoza-Huesca.

c Includes Madrid-Valencia and Bifurcation Albacete-Alicante.

Table 8. Construction cost per high-speed rail corridor in service (constant $€_{2013}$ ). Source: Betancor and Llobet (2015).

Despite the economic crisis and its impact on budget constraints, the Spanish government has not paralyzed its project of network extension in the last years. The aggregate amount of annual investments has decreased, but its share of the total investments in railways infrastructure have kept a similar path, representing about the $70 \%$ of total investments. On available figures, we estimate total investments to be close to 30 billion euro in the period 2009-2016. ${ }^{14}$

\footnotetext{
${ }^{13}$ The report does not include previous lines because ADIF was created in 2005.

${ }^{14}$ The only public information is on planned investments and not the executed ones (information regarding realized investments is aggregated within the railway category, making impossible to distinguish the part of it devoted to high-speed rail lines). The planned investment is over 35 billion euro. We know from the report of the Accounting Court (Tribunal de Cuentas, 2015) that the executed investments in 2013 in high-speed rail were the $85 \%$ of the planned investments. Assuming this figure as a constant percentage, we would leave accumulated investments in the period 2009-2016 close to 30 billion euro.
} 
These investment efforts will certainly continue in the future. According to the current budget the total investment in the rail sector will reach around 5 billion euro in 2016, 5\% more than the investment of 2015 (67\% in highspeed rail and $8 \%$ in conventional rail). Adif investments were financed mainly with increasing bank debt, together with contributions from the State and collections of European funds. Indeed, many of these lines enjoyed the assistance of the different European funds that were available for infrastructure projects. The amounts of this funding per line are reported in Table 8. So far, Spain has devoted more than 11 billion euro from European Funds to construct its high-speed rail infrastructure, its assessment and/or its planning.

\begin{tabular}{ll}
\hline Corridor & $\begin{array}{l}\text { Million Euro } \\
\text { (Current terms) }\end{array}$ \\
\hline Madrid-Andalucia & 1.154 \\
Madrid-Barcelona-French Border & 3.432 \\
Madrid-Toledo & 67 \\
Madrid-Valladolid & 2.014 \\
Valladolid-León & 123 \\
Madrid-Levante & 2.206 \\
Madrid-Galicia & 385 \\
Baque country-French border & 67 \\
Madrid-Extremadura-Portuguese border & 429 \\
Antequera-Granada & 555 \\
Antequera-Murcia & 322 \\
Venta de Baños-French Border & 40 \\
León-Asturias & 649 \\
\hline Total & 11.443 \\
\hline
\end{tabular}

Table 9. European funds co-financing

\section{The forms of delusion}

Literature on megaprojects generally refers to two problems: optimism bias in the demand estimations and cost overrun with respect to investment cost forecasts. The well-known seminal work of Flyvbjerg et al. (2003) documents how systematically forecasts for megaprojects are wrong, underestimating the costs and overestimating the demand. They also stress that these biases are deliberate and tend to drive decisions in the direction of building unjustified infrastructure. The fact that only roads, whose impact is hardly accepted by citizens, demand appears systematically underestimated (Næss et al., 2005 and Flyvbjerg, 2007) just reinforces the hypothesis.

However, not all megaprojects have shown both of these problems (overruns and demand biases) and may give the impression of a success, in terms of passengers, quality and even cost containment. We then need a more structured approach to study megaprojects, going beyond the illusion of success. In fact, we stress that the "megaproject issue" consists in a mismatch which is not formal (that forecasts are wrong and/or falsified), but mostly substantial: the planning choices do not match with the potential demand. This means that, ex-post, realised schemes results unjustifiable from the economic or environmental viewpoint, but supported anyway and driving to unsuccessful results. Deluding, but well forecasted.

In this sense, the two cases presented in this paper represent useful examples of this need to extend the attention on megaproject beyond formal aspects into substantial ones. The Italian high-speed lines did not present a high cost-overrun since construction started. But it did cost much more than any other comparable infrastructure in Europe because of technical and organisational choices adopted. Spanish demand forecasts were not optimistically biased, but are unconnected with actual mobility requirements.

We classify the delusions of success of HSR project into three types, namely:

- overdesign;

- overinvestment;

- overquality.

In the following we will describe all of them by means of Italian and Spanish HS cases.

\subsection{Overdesign}

A first issue - not directly connected with cost-overruns - is overdesign: an infrastructure could be designed in a 
redundant way, adopting excessive design parameters and consequently costing more.

The Italian high-speed line is worldwide known as a case of extraordinary high construction costs (see back Table 6 vs. the Spanish one Table 7). However, this high cost is not due to an increase during construction, for example due to unexpected factors or on-going modifications.

The infrastructure manager RFI, in a public consultation to the Parliament by RFI in 2007 (and reported by the Corte dei Conti, 2009, pag. 19), reports the increase in the cost of the line between the initial design phase, when the technical characteristics were not fully defined, and the final phase of construction, with all elements fixed.

Figure 5. Trend of construction costs of Italian HSR. Real and actual values. Source: Corte dei Conti, 2009.

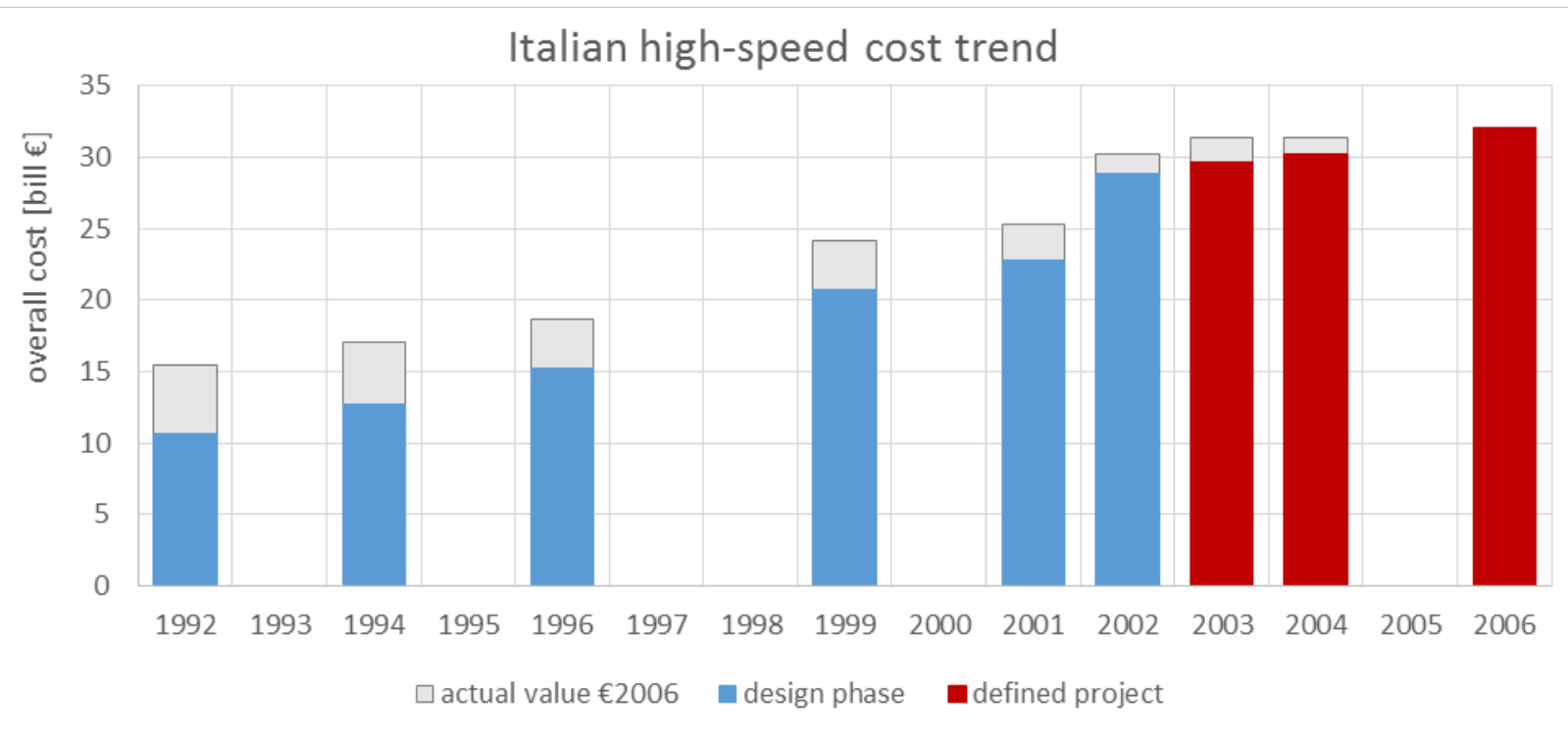

As visible in Figure 5, the larger increase of the costs occurred in the initial phase and is due to the change of project characteristics and to the construction contracts awarding model (see next section for a discussion). These factors are precise choices of the designer and decision-maker, and not as "cost-overruns" occurred because of inadequate risk management, unexpected facts or external requests such as environmental standards.

The most radical design change occurred in 1997, when the Parliament requested a total redefinition of line characteristics. Before 1997, the line was conceived as a fast line, separate from the rest of the existing network and accessible to light high-speed rolling stock only. Afterwards, the line became a full doubling of the existing line, with numerous connections (for many $\mathrm{km}$ ), and capable to host also heavy freight trains. The first fact made the extension much longer than the about $900 \mathrm{~km}$ between Turin and Naples. The second one required a much more demanding infrastructure, with low slopes and with different equipment. In addition, a large part of the line was decided to be built aside to highways, in order to prevent further land consumption. However, this required to rebuild all bridges and all junctions, to overpass both the highway and the rail line. This "excessive” design have 
almost doubled the cost of the line in real terms, from 15.5 billion $€$ of 1996 to 29.6 of 2003.

All of these must be considered as deliberate choices and not as unexpected facts or extra costs due to longer building phase, which occurred but account for just $+11 \%$ in real terms between 2003 and 2006. In other words, these are not "cost increases", but costs due to specific design characteristics, imposed by a political choice. In the light of what happened after - but could have been foreseen - these choices represent a waste of money. In particular, no high-speed cargo service exists, many interconnections are not used or used few times a day and the cost of uselessy rebuilding the parts of highways (between Milan and Turin in particular) are accounted as rail costs.

\subsection{Overinvestment}

A second issue deals with the excessive extension of lines (and possible of services) in relation with the existing and future demand. This overinvestment can be easily demonstrated with Cost Benefit Analyses, comparing the cost of investment and running of lines and trains, with the benefits, direct and indirect. Again, a high-speed network could be perfectly working and also performing in an excellent way in terms of quality, but representing an overinvestment, i.e. a case of supply exceeding any reasonable estimation of demand.

As highlighted in previous works (Albalate and Bel, 2011; Albalate, Bel and Fageda, 2015), current infrastructure stock in Spain appears disproportionate respect to demand and use. Spain is far behind any comparable country with high-speed rail network in terms of total volume of passengers and intensity of use (passenger-km per km of network). The total volume of passengers per $\mathrm{km}$ of network in Spain was almost 12.0 passengers in 2014, accounting for any passenger using the infrastructure, including non-high-speed services. Even excluding Asian networks (reviewed by Albalate and Bel, 2015), Spain perform worse than European countries like Italy with 30.0 passengers per $\mathrm{km}$ and France with more than 60.0. Moreover, if we consider the intensity of use in terms of passengers-km per km of network, we realize that Spain is well below Germany, France and Italy (see Table 9).

\begin{tabular}{ccc}
\hline Country & $\begin{array}{c}\text { Passenger-Km } \\
\text { (Billions) }\end{array}$ & $\begin{array}{c}\text { Passenger-km per Km } \\
\text { (Billion pass-km/thousand Km) }\end{array}$ \\
\hline France & 51.09 & 25.1 \\
\hline Germany & 24.75 & 24.4 \\
\hline Italy & 12.79 & 13.9 \\
\hline Spain & 11.18 & 4.5 \\
\hline Source: European Commission. EU Transport in figures-Statistical pocketbook 2014.
\end{tabular}

Note: High-speed rail transport covers all traffic with high-speed rolling stock (incl. tilting trains able to travel at $200 \mathrm{~km} / \mathrm{h})$.

Table 10. Use and intensity of use of high-speed rail networks by country (2012).

This situation can be hardly considered a surprise if we take into account the infrastructure supplied for the potential demand of the country, especially with respect to other countries. Table 10 displays information on the high-speed rail network in different countries. The second column shows the number of km per capita and the fourth the number of $\mathrm{km}$ in operation and under construction by 2014. Spain leads that ranking with a long distance to France; and its distance will increase with new line openings and extensions currently under way.

\begin{tabular}{cccc}
\hline Country & $\begin{array}{c}\text { Km of network/ } \\
\text { million inhabitants }\end{array}$ & Country & $\begin{array}{c}\text { Km of network/ } \\
\text { million inhabitants } \\
\text { (Including in construction) }\end{array}$ \\
\hline Spain & 54 & Spain & 79 \\
France & 31 & France & 43 \\
Belgium & 19 & Japan & 23 \\
Japan & 16 & Belgium & 19 \\
Italy & 15 & Germany & 18 \\
Taiwan & 15 & Italy & 16 \\
Germany & 13 & Taiwan & 15 \\
Austria & 11 & Turkey & 13 \\
South Korea & 11 & Switzerland & 13 \\
China & 8 & South Korea & 12 \\
Turkey & 8 & Austria & 11 \\
Holland & 7 & China & 11
\end{tabular}




\begin{tabular}{cccc} 
Switzerland & 4 & Holland & 7 \\
United Kingdom & 2 & United Kingdom & 2 \\
\hline
\end{tabular}

Table 11. Longitud de la red de alta velocidad en operación (September, 2014). Source: Network, International Union of Railways (UIC), September 2014. Population, Eurostat.

In addition, a recent cost-benefit analysis has shown that high-speed rail covers variable costs in both financial and social terms in three out of the four corridors, with the exception of the financial analysis of the corridor MadridValladolid (Betancor and Llobet, 2015). But in no case investment is covered, which means that, considering current levels demand and reasonable future projections, these investments will not be profitable either from the financial nor social perspectives.

In Italy, estimated traffic in 2013 (see section on demand figures) already exceeded the thresholds of patronage for investment to be worthwhile in terms of cost-benefit (estimated by Beria and Grimaldi, 2011) on all sections but the Milan-Turin.

\begin{tabular}{ccc}
\hline Corridor & Financial Analysis & Social Analysis \\
\hline Madrid-Barcelona & $45.94 \%$ & $79,61 \%$ \\
\hline Madrid-Andalusia & $11,37 \%$ & $45,09 \%$ \\
\hline Madrid-Levante & $9,60 \%$ & $42,54 \%$ \\
\hline Madrid-Valladolid & $-1,41 \%$ & $19,03 \%$ \\
\hline
\end{tabular}

Table 12. Percentage of investment recovery by type of analysis during the life-cycle of the infrastructure. Source: Betancor and Llobet, 2015

The Spanish situation damages the accounts of the infrastructure manager ADIF. According to the Tribunal de Cuentas (2015), by the end of 2013, the amortized cost of the debt that ADIF will have to return from 2017 already amounted to 9,142.6 million euros. Current access prices charged to Renfe are insufficient to cover its costs and, consequently, to achieve economic sustainability.

As final illustration of this overinvestment, it is not unusual to find expensive but underused rail terminals (stations) along the HSR network. Only six stations were used by a million passengers (or close to), while 13 - about one third of the total number of stations- did not reach the 250 daily passengers in 2012. For instance, the Station in Ciudad Real received 224 passengers a day, while Cuenca gave service to 164 daily passengers, Calatayud to 109, Antequera to 92, Guadalajara - Yebes to 85, Huesca to 79, Puertollano to 77, Albacete to 76, Puente Genil to 46 and Requena - Utiel to 21, etc.

Similarly to overdesign, also overinvestment is the outcome of a precise choice, aiming at providing an extensive network, but barely used at a level capable to cover, in the best case, only the marginal running cost.

\subsection{Overquality}

A third issue deals with the quality of the infrastructure built. This fact is particularly visible in stations, often conceived more as a "monument" overcoming the pure function of transport infrastructure. Of course the quality - and moreover the architectural quality - are subjective facts and it is out of the scope of this paper to discuss the benefits of beautiful buildings. However, it is undeniable that some architectures cost more than comparably functional buildings without some design choices.

We can find some cases both in Spain and Italy, limiting to the two countries of this paper. All new Italian stations built outside cities and in addition to the existing central station have been designed by famous international architects and are characterised by catchy buildings often presented as landmarks. The new Reggio Emilia AV "Mediopadana" is the most relevant case, designed by Santiago Calatrava and costed $79 \mathrm{M} €$, together with Napoli Afragola by Zaha Hadid, in construction for $61 \mathrm{M€}$. Both are built in non-urbanised areas. Also Turin and Florence underground stations present buildings and spaces characterised by monumentality and cost 79 M€ and 350 M€ respectively (excluding the tunnels).

\begin{tabular}{lccccc}
\hline \multicolumn{1}{c}{ station } & cost (station only) & surface (sqm) & tracks & & cost $€ /$ sqm \\
\hline Firenze Belfiore & $350 \mathrm{M} €$ & 48,700 & 4 & underground & 7,187 \\
Torino Porta Susa & $79 \mathrm{M} €$ & 37,000 & 6 & underground & 2,135 \\
Napoli Afragola & $61 \mathrm{M} €$ & 38,000 & 6 & greenfield & 1,605
\end{tabular}




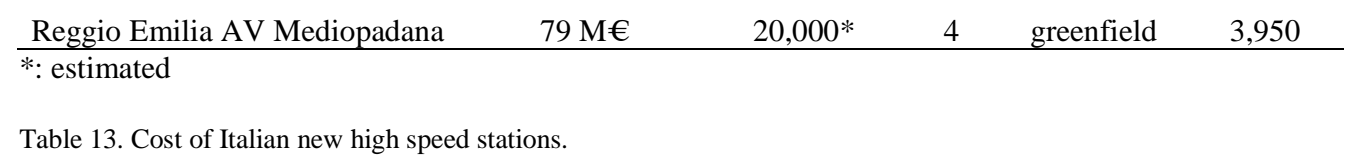

Also some Spanish stations are conceived as landmark buildings, such as Zaragoza Delicias, at the centre of important urban redevelopments, but largely redundant in terms of space available to travellers and consequently of cost.

Another form of overquality can be the speed of the lines. Travel time depends not only on the maximum speed of the line, but also on the frequency of stops, station entrance and exit, acceleration, etc. On the other side, the cost of a line depends directly on the maximum speed allowed, influenced by the geometry of curves. This means that increasing the top-speed of a section influences its cost, but may translate into just a few minutes of time savings. In this sense, also deciding for a standardised speed - usually $300 \mathrm{~km} / \mathrm{h}$ or more - makes the line more performing, but maybe excessively demanding in terms of cost and benefit-cost ratio, especially in low-demand section.

\section{The causes of mismatch and optimism}

The previous sections showed that, beyond mismatches between forecasted and actual costs and demand, the core of the problem lays in the extremely low potential demand (in Spain and limitedly in Italy) and in the design choices which rose costs (in Italy and limitedly in Spain). This section will discuss the causes of the planning optimism, which drove to severe delusions.

\subsection{The role of the State}

We already commented that the planners had an active role in the choices that translated into excessive costs and scarce demand. When analysing the extension of the network of HSR, three political reasons stand out as fundamental factors: political centralization, national prestige, and promotion of domestic industry (Preston, 2013: 12). All of them are particularly relevant in Spain, while in Italy and other countries (with the relative exception of China), only the promotion of domestic industry played a role.

First, the HSR in Spain does not respond to a transport policy at the service of productivity and welfare, but it is a peculiar case of pure administrative ideology: centralization (Albalate, Bel and Fageda, 2012). The bipartisan focus posed on the connection of provincial capitals with the centre of the peninsula ${ }^{15}$, as a form of "nation building" 16 clarifies the concept. Using infrastructure policy for nation building in Spain has been a regular pattern in railway policy since the XIX century (Bel, 2011) and in all types of interurban infrastructure policy since the XVIII century (Bel, 2012). In this regard, demand is not a key factor in investment decisions, but providing a similar level of supply of infrastructure (quantity as well technology) to all radial routes from the political capital, whether it is intensively used or not.

The use of rail connections as a tool for centralization has not been a driver - or very weak - in Italy in the Nineties. The line Milan - Venice, similarly important, has been postponed not for political choices, but because congestion on the North - South was perceived as more severe. The only similar political arguments in Italy is the connection of Southern Regions with the North, on the basis of an "infrastructural gap” jeopardizing Southern economy. In this sense, the forthcoming extensions towards Bari, Reggio Calabria and Sicily are presented as economyfostering actions, even if the demand on these corridors is and will remain much scarcer than in the main sections. Secondly, HSR policy has been, especially in Spain, a tool for achieving 'national prestige' given the label of modern transportation technology involved in HSR. This has been oriented on one side, to gain political support for the successive governments. On the other, to provide reputation and to allocate budgetary funds to the largest Spanish construction firms. Again, in Italy, national prestige, per se, has not been a dominant argument, even if used in some cases.

The last objective is intimately connected with the third rationale stated above: to promote national industry. As explained in Bel, Estache and Forcaud (2014), five Spanish construction companies ranked among the largest 50 construction firms worldwide, and four among those five have been very active in obtaining contracts to build HSR lines: ACS, FCC, Sacyr, and Ferrovial. All these four companies have developed also a close relationship with the main Spanish political parties, by means of donation of funds, and by appointing politicians (formerly in top governmental positions) to the company board (Castells and Trillas, 2013). Also in Italy all construction works

\footnotetext{
${ }^{15}$ Diario de Sesiones del Congreso, April 25, 2000, p. 29.

${ }^{16}$ Magdalena Alvarez, media group Vocento, May 11, 2008.
} 
have been carried out by national companies, using a "general contractor" scheme: the general contractor must provide the line in operation to the concessionaire (initially TAV SpA, later merged with RFI) and is paid with lump sum. The physical construction is done by other companies, but works are awarded by the general contractor as between private parties and without any control on the expenditure. Moreover, the award of the concession to the general contractors have been awarded without any competitive tender and before an executive project was available (ANAC, 2015). This fact has been recognized by the CEO of Ferrovie dello Stato as one of the main causes of extracosts (Corte dei Conti, 2009, pag. 19): 14 to 20\% more, quantified in 4 to 6 million Euros per km of line. The freedom of the General Contractors to manage the design and the construction is, indirectly, also one of the causes of the overdesign documented above.

This convergence of politics and business has been justified, not only in Spain (Crozet, 2014), as an industrial policy intended to promote national champions, which provides an incentive to emphasize the supply side in the extension of the infrastructure. More prosaically, also private interests and corruption could have played a key role (as will be clarified by the inquiry "Sistema", presented on March 16"th 2015 and whose trial is still ongoing). Overall, this has contributed to overinvestment in the HSR network, and to aggravate the problem of the mismatch between supply and demand, financed by the taxpayers.

\subsection{Planning choices and demand characteristics}

While the side of excessive costs can be explained with technical choices and building procedures, the disappointing figures on demand - in Spain, but also on sections of Italian or French lines - can find an explanation into geography and planning choices.

The geography and the urban structure has an unavoidable influence on demand. Figure 6 compares the distribution of Italian and Spanish population and the HS lines built. The before mentioned centralized branching shape of Spanish HS (Cañizares et al., 2014) is amplified by population distribution: Madrid, at the centre of the country, is surrounded by hundreds of km without large cities. Consequently, the trains run for long distances or stop in small centres. This situation is characterized by limited demand, long trips, high maintenance costs, long distances covered by trains and direct competition with air transport, intrinsically cheaper for longer distances. To reach reasonable load factors, the train company is forced to keep prices low, but this makes the breakeven difficult. 


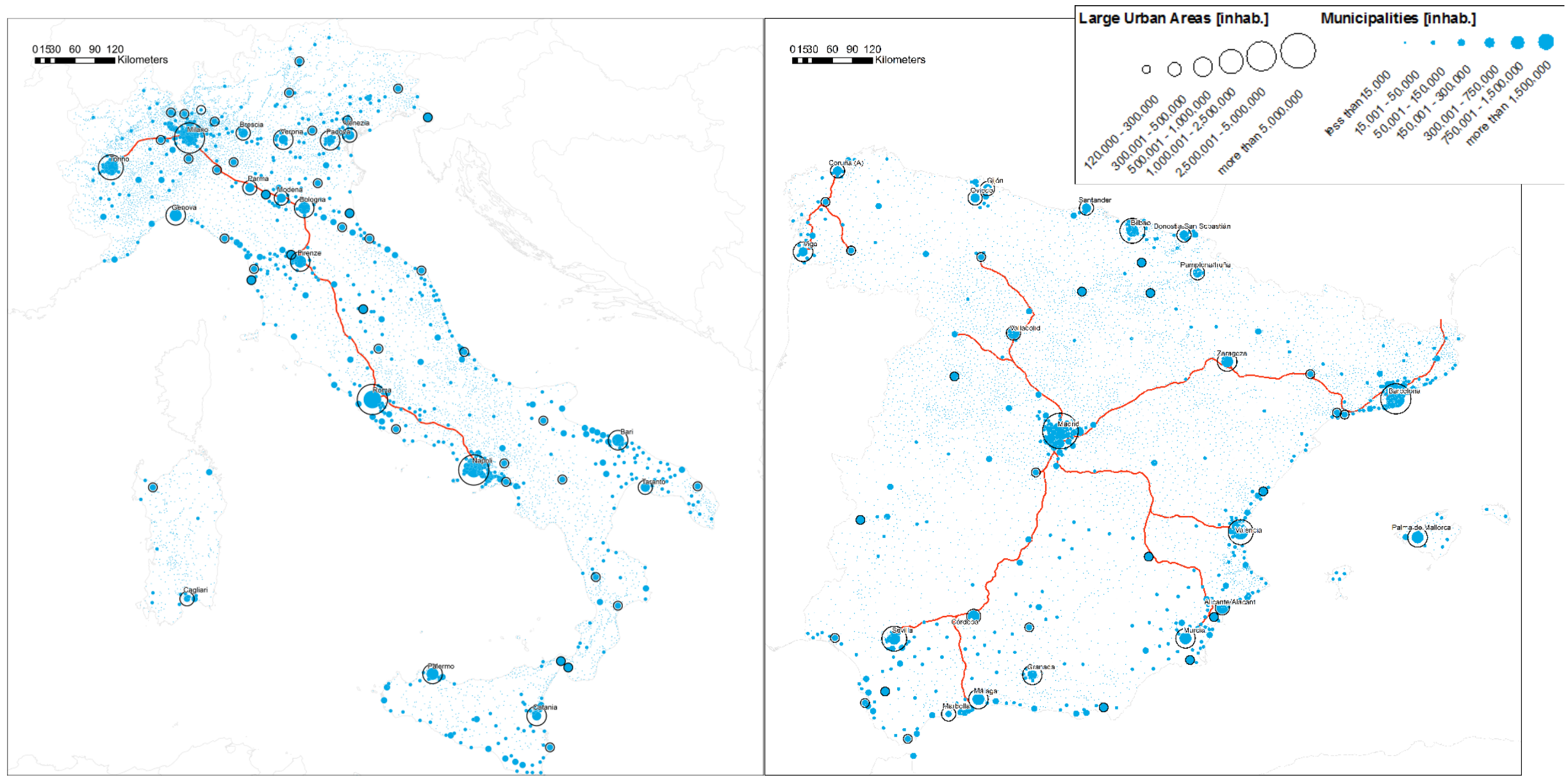

Figure 6 - High speed rail infrastructure and population (our elaboration).

Data sources: World Political Boundaries - ShareGeo @ University of Edinbourgh; Large Urban Areas 2012 - Eurostat; Municipalities 2011 Spain - Instituto Nacional de Estadística (INE); Municipalities 2011 Italy Istituto nazionale di statistica (ISTAT) 
Italian situation is very different. The sole existing line, 1,000 km long instead of 2,700 $\mathrm{km}$ in Spain, serves the main cities and consequently the core of potential demand. Moreover, the average distance between main centres is much shorter. For example, Milan and Bologna are separated by $180 \mathrm{~km}$, a distance for which a fast train is extremely competitive, demand density very high and competition of air transport absent. The trains on the line stop in 2-3 intermediate cities, helping the load factors and the profitability, of course at detriment of commercial speed, which in fact is lower than in the Spanish case. Finally, one must not forget the role of competition in fostering the demand. Since 2012, two train companies - the public Trenitalia and the private NTV - are competing on the entire HS network (Bergantino, 2015; Beria and Grimaldi, 2016). The effect in terms of quality, supply and fall of average prices is evident and documented (Bergantino et al., 2015; Beria et al., 2014).

The problem of Spanish network is a threat for any HS network, as soon as the network extends outside the core of demand, whatever is the urban structure. The success, real or apparent of the core lines, can be such that more and more cities claim with political arguments a connection with HS, resulting in lines increasingly marginal. These lines have the same cost (or higher, like the case of Italy where future extensions will be across mountainous areas to Genova, Bari and to the South), but less potential passengers and revenues. Even France had recently a rude awakening, with the planned extensions financed with difficulty and at price of high risks for both private and public sector (Crozet, 2014).

\section{References}

Albalate, D. \& Bel, G., 2012b. The Economics and Politics of High Speed Rail: Lessons from experiences abroad. Rowman and Littlefield (Lexington Books), Lanham, Maryland.

Albalate, D. \& Bel, G., 2015. “La experiencia internacional en alta velocidad ferroviaria”, Documentos de Trabajo FEDEA $2015-02$.

Albalate, D.\& Bel, G., 2011. “Cuando la economía no importa: Auge y esplendor de la Alta Velocidad en España”, Revista de Economía Aplicada, 19(55), 171-190.

Albalate, D.\& Bel, G., 2012a. “High Speed Rail: Lessons for policy makers from experiences abroad”, Public Administration Review, 72(3), 336349.

Albalate, D., Bel, G. \& Fageda, X., 2015. "When supply travels far beyond demand: Causes of oversupply in Spain’s transport infrastructure”, Transport Policy, 41, 80-89.

Albalate, D., G. Bel \& X. Fageda, (2012) "Beyond the efficiency-equity dilemma: Centralization as a determinant of government investment in infrastructure”, Papers in Regional Science, 91(3), 599-615.

Bel, G. 2011. "Infrastructure and nation building: The regulation and financing of network transportation infrastructures in Spain (1720-2010)", Business History, 53(5), 688-705.

Bel, G. 2012. Infrastructure and the Political Economy of Nation Building in Spain, 1720-2010. Eastbourne: Sussex Academic Press.

Bel, G., 1997. "Changes in travel time across modes and its impact on the demand for inter-urban rail travel", Transportation Research-E, 33(1), 43-52.

Bel, G., 2007. “Política de transporte: ¿Más recursos o mejor gestión?”, Economistas, 111, 279-284.

Bel, G., Estache, A. \& Forcaud, R. 2014. “Transport infrastructure failures in Spain: mismanagement and incompetence, or political capture?”, T. Søreide \& A. Williams, eds. Corruption, grabbing and development. Real World Challenges. Edward Elgar, 129-139.

Bergantino, A. S. (2015). Incumbents and new entrants. In: Finger, M., \& Messulam, P. (Eds.). Rail Economics, Policy and Regulation in Europe. Edward Elgar Publishing. Cheltenham (UK).

Bergantino, A. S., Capozza, C., \& Capurso, M. (2015). The impact of open access on intra-and inter-modal rail competition. A national level analysis in Italy. Transport Policy, 39, 77-86.

Beria P., Grimaldi R. (2016, forthcoming). Reality and opportunities for on-track competition in HSR. In: Albalate, D., Bel, G. (2016). Evaluating High-Speed Rail: Interdisciplinary Perspectives. Routledge, London.

Beria, P., \& Grimaldi, R. (2011). An early evaluation of Italian high-speed rail projects. Tema - Journal of Land Use, Mobility and Environment, 4(3), 15-28.

Beria, P., and Ponti, M. (2009). Regulation of investments on transport infrastructures in Italy, 2nd Annual Conference of Competition and Regulation in Network Industries, Brussels, Belgium, November 20, 2009. Available at: http://www.jcrni.org/extranet/index.php

Beria, P., Redondi, R., \& Malighetti, P. (2014). The effect of open access rail competition on average prices. The case of Milan - Ancona. Presented at the XVI Meeting of the Italian Society of Transport Economics (SIET). Florence (Italy).

Betancor, O \& Llobet, G. 2015. “La contabilidad financiera y social de la alta velocidad en españa” Estudios sobre la economía española - 2015/08. Betancor, O., \& Llobet, G. (2015). Contabilidad Financiera y Social de la Alta Velocidad en España (No. eee2015-08). FEDEA.

Campos, J., \& De Rus, G. (2009). Some stylized facts about high-speed rail: A review of HSR experiences around the world. Transport Policy, 16(1), 19-28.

Cañizares, M. P. M., Pita, A. L., \& Álvarez, A. G. (2014). Structure and topology of high-speed rail networks. Proceedings of the Institution of Civil Engineers-Transport. Vol. 168, No. 5, 415-424. 
Castells, P. \& Trillas, F. (2013). “The effects of surprise political events on quoted firms: the March 2004 election in Spain. SERIES, Journal of the Spanish Economic Association, 4(1), 83-112.

Corte dei Conti (2009) Relazione sul risultato del controllo eseguito sulla gestione finanziaria di Rete Ferroviaria Italiana (R.F.I.) S.p.A. per l'esercizio 2007 [in Italian]. Delibera 44-09, Roma (Italy).

Crozet, Y. (2014). Extension of the high speed rail network in France: Facing the curse that affects PPPs in the rail sector. Research in Transportation Economics, 48, 401-409.

De Rus, G. \& Inglada, V., 1993. “Análisis coste-beneficio del tren de alta velocidad en España”, con Vicente Inglada. Revista de Economía Aplicada, 3, 27-48.

Dell'Alba, R., \& Velardi, V. (2015). Forecast of passengers demand on HS rail services: a system of models. Railway Engineering - Ingegneria Ferroviaria. 70(3), 215-263.

Eurostat (2015). Cities (Urban Audit). Database: Population on 1 January by age groups and sex - larger urban zone [urb_lpop1]. Last update: 0906-2015.

Flyvbjerg B. (2007), "Policy and planning for large-infrastructure projects: problems, causes, cures”, Environment and Planning B: Planning and Design, Vol. 34, 578 - 597.

Flyvbjerg B. et al. (2003), Megaprojects and risk. An anatomy of ambition, Cambridge U.P., Cambridge (Great Britain).

Næss P. et al. (2005), Geographical bias in traffic forecasts? An analysis of accuracy in road-traffic forecasts in cities vs. peripheral regions, proceedings of AESOP 2005 conference, Wien (Austria).

Perl, A. D., \& Goetz, A. R. (2015). Corridors, hybrids and networks: three global development strategies for high speed rail. Journal of Transport Geography, 42, 134-144

Preston, J. 2013. The Economics of Investment in High Speed Rail. Summary and Conclusions. OECD International Transport Forum, Discussion Paper 2013-30.

ResPublica (2010). Strumenti innovativi per il finanziamento delle infrastrutture di trasporto, Report, Milan (Italy)

RFI (2007). Rete AV/AC. Analisi dei costi, [in Italian], presentation, Rete Ferroviaria Italiana, Ferrovie dello Stato, Roma (Italy).

Tribunal de Cuentas 2015. Informe de fiscalización de la financiación de las infraestructuras ferroviarias en el periodo 2011-2013. Madrid. 30 de abril de 2015

Vickerman, R. 1997. “High-Speed rail in Europe: experience and issues for future development”, Annals of Regional Science 31(1), 21-38. 